\title{
EXPENDITURE ON RESEARCH AND DEVELOPMENT IN BRITAIN
}

\begin{abstract}
$\mathrm{I}^{\mathrm{N}}$ $N$ the final section of its annual report for 1961-62*, the Advisory Council on Scientific Policy again reviews the expenditure on scientific and technical research and development, which in 1961-62 is estimated at $£ 634$ million or about 2.7 per cent of the gross national product, of which about $£ 67$ million was capital expenditure. Private industry carried out about 58 per cent of total research and development, universitios and technical colleges being responsible for $5 \cdot 1$ per cent, research associations for $1 \cdot 3$ per cent, Research Councils for $3 \cdot 6$ per cent, and public corporations for 3.4 per cent. On the other hand, the Government provided 60.7 per cent (£385 million) of the finance, of which 38.7 per cent was from defence departments and 4.6 per cent from the research councils, while private industry provided 33.6 per cent (£213 million), only 0.2 per cent coming from the universities and technical colleges. Of current expenditure by the Government, $£ 86 \cdot 4$ million was by defence departments, $£ 45.7$ million on eivil research and development, and $£ 19.4$ million on the research councils. Technical colleges spent $£ 1.8$ million, universitios $£ 24.8$ million, research associations $£ 6.5$ million, public corporations $£ 15.4$ million, and private industry $£ 340.8$ million.

The proportion of the gross national product expended on research and development continues to rise, from $1 \cdot 7$ per cent in 1955-56 and $2 \cdot 3$ per cent in 1958-59. Expenditure by universities and technical colleges has risen from $£ 14.4$ million in $1955-56$ to $£ 32.4$ million, by research associations from $£ 4.9$ million to $£ 8.1$ million, by public corporations from $£ 5.8$ million to $£ 21.4$ million, by research councils from $£ 10$ million to $£ 23$ million, and by private industry from $£ 185$ million to $£ 367.7$ million, while that by defence departments has only risen from $£ 65.7$ million to $£ 93.2$ million. Government expenditure in work carried out in private industry was nearly $£ 177$ million, and most of this was in the electronics, electrical
\end{abstract}

* Annual Report of the Advisory Council on Scientific Policy, 1961-1962. (C'mnd. 1920.) Pp. vi+45. (London: H.M. Stationery Office, 1963.) 3s, net. See also p. 825 of this issue of Nature. engineering, and especially the aircraft industry. Total expenditure in the United States in 1961-62 is estimated at about $£ 5,360$ million, or 2.89 per cent of the gross national product, excluding capital expenditure.

A note on the scope and methods used in this inquiry into research and development expenditure appended to the report gives the qualified manpower employed on research and development in private industry as about 31,000 and the number of science mathematics graduate teachers in grant-aided schools in England and Wales as 20,055 and in Scotland 5,109, increases of 968 and 85 , respectively, on the previous year. The additional scientific manpower is computed from 6,844 first degrees and diplomas awarded in pure science in 1960-61, 3,982 in technology, 620 diplomas in technology, 158 associateships of educational institutions, and 5,885 new members of scientific and technological professional institutions. Government expenditure on eivil research in 1960-61 was $£ 18.19$ million and is estimated at $£ 21.5$ million in 1961-62 and $£ 27 \cdot 2$ million in 1962-63. For agriculture, forestry, fisheries and food the figures are $£ 10 \cdot 66$ million, $£ 12 \cdot 7$ million and $£ 12.9$ million, respectively; for industry and communications, $£ 20$ million, $£ 19 \cdot 2$ million and $£ 23$ million; medical and health, $£ 5,255$ million, $£ 6 \cdot 3$ million and $£ 6.66$ million; overseas research, $£ 1.52$ million, $£ 1.5$ million and $£ 1.6$ million; universities and learned societies, $£ 19.37$ million, $£ 21.4$ million and $£ 23.9$ million; and for nuclear science, $£ 54 \cdot 1$ million in $1961-62$ and $£ 56 \cdot 7$ million in 1962-63. Of the expenditure on Research Councils, estimated at $£ 36.4$ million in 1962-63 compared with $£ 31.6$ million in 1961-62 and $£ 27.7$ million in 1960-61. $£ 17$ million was for current and $£ 5 \cdot 1$ million for capital expenditure on the Department of Scientific and Industrial Research with a scientific staff of 3,650. For the Agricultural Research Council the corresponding figures are $£ 6.8$ million, $£ 954,000$ and 2,672 ; for the Medical Research Council, £5.4 million, $£ 441,000$ and 1,883; and for the Nature Conservancy, $£ 534,000, £ 56,000$ and 121.

\section{TRAINING OF GRADUATE SCIENCE TEACHERS IN BRITAIN}

\begin{abstract}
A
REPORT on the training of graduate science teachers in England, Wales and Scotland, issued as the first section of Part 2 of the Science and Education Report of the Science Masters' Association and the Association of Women Science Teachers *, is based largely on information supplied by the twenty-three university departments of education in England and Wales in answer to a questionnaire. Some seventy senior science teachers were also consulted and twenty-seven others with less than five years' experience, and a joint meeting was held with the Standing Conference of Heads of University Departments of Education in December 1960.

The report points out that the present shortage of science teachers and consequent rapid promotion to senior posts may quickly cause the young graduate to be faced with the general supervision and maintenance of a laboratory as well as to be asked to produce new teaching syllabuses and to devise new courses. It is hoped that

* The Training of Graduate Science Teachers in England, Wales and Scotland. (A section of Part II of the Science and Education report issued by the Science Masters' Association and the Association of Women Science A.W.S.T., 1963.) 2s. net.
\end{abstract}

he will wish to keep himself informed of developments within and on the fringe of his own subject as well as in the field of education. This clearly requires a comprehensive course of study, not merely coaching in practical techniques, and the sub-committee responsible for the report submits that a successful teacher is one who can convey clearly and accurately both the established knowledge of science and the spirit of scientific inquiry and can indicate the part which science plays in the wide field of human achievement, practical and intellectual. The Associations believe that all intending science teachers should undergo an effective training course, but they also believe that the potential value of present courses is often not realized.

Their inquiries revealed that eight out of twenty-three departments of education had no practical facilities, four had a small room or laboratory, seven had one laboratory, and four had two or more laboratories. Many of the small rooms were for one subject only, and some depart. ments used facilities elsewhere in the university. Only eleven departments held laboratory courses, ranging from five to sixty hours per year, and the money spent on apparatus averaged $£ 28 s$. per student per year; in fitting out new 
laboratories the capital expenditure in 1959-60 was $£ 9$ per student. The sub-committee concluded that the facilities provided for practical work were quite inadequate both in time and in accommodation. If practical work is to be given adequate time, science students must be propared either to devote more hours weekly to their training, or to have their training extended beyond the present university terms.

To overcome the inadequacy of laboratory accommodation, the report recommends the establishment of Science Teaching Centres in all universities, in the departments or institutes of education or elsewhere. These centres should have adequate laboratory accommodation, be organized by a director and have a panel of visiting school teachers. It is suggested that the establishment of such centres would help to meet the present need for refresher courses for established teachers and for part-time courses leading to a higher professional qualification, such as university diploma in the teaching of science. It is also recommended that the training course to be taken by all intending science teachers should pay adequate attention to general principles of education and to studies in the philosophy, method and social consequences of science. School practice should comprise a complete school term and only in schools where adequate supervision and help are provided. There should be more liaison botween school supervisor and departmental tutor both at the personal and professional level. Departments of Education should be asked to consider the merits of continuous assessment and the time spent on method and practical work, and Department of Education staffs and local branches of the Science Masters' Association and the Association of Women Science Torchers should ensure that effective and continuous contact exists between each Department and the science teachers in its area. Conditions in Scotland are regarded as in many ways in advanct) of those in England and Wales; but there is considerable dissatisfaction with the student/staff ratio and the inadequate provision of rooms and equipment in the: colleges.

\section{CHALLENGES OF SCIENCE IN SOUTH AFRICA}

$\mathrm{I}^{\mathrm{N}}$ his presidential address to the Diamond Jubilee Congress of the South African Association for the Advancement of Science at Cape Town, July 1962, Prof. J. P. Duminy, under the title "The Challenges of Science To-day", discussed more particularly the universal shortage of manpower which, he suggested, arises out of the unplanned and unexpected advances in technology in the past decade--out of what can be deseribed as an explosion in the field of scientific knowledge. But for this, South Africa might have been able to cope with its internal post-war domands for trained personnel. However, extreme difficulty is now being experienced in attracting mon from abroad to institutions there and in training South Africans in their own universities to meet the manpower needs.

South Africa has never enjoyed the means of providing facilities at its universities necessary for training men to the levels of teaching and research in science and tochnology which are essential. Many of those who go overseas in order to obtain qualifications nevor return. Some mobility and interchange are desirable, but for soveral years the movement has been consistently one way. Investigations into the sources of trained manpower have shown that the universities will be powerless to play their full part unless the interest of youth is aroused and larger. numbers are stimulated to take up careers in science and technology. The Manpower Development Foundation. created under the auspices of the Association and in collaboration with the Federation of Science Teachers' Associations, seeks to improve the teaching of science in the schools. Publication of a periodical dealing with methods and material for teaching physies, chemistry. mathematics and biology is planned. A significant contribution is also being made by the Permanont Exhibition of Modern Science.

In conclusion, Prof. Dunning, observing that seience is not independent of philosophy and that philosophical thinking is not incompatible with scientific concepts. urged that the schism between tho humanities and the sciences must be healed and science enabled to make it: full contribution in our thinking about the realities of human existence and the rolations betweon human heings.

\section{PROGRESS AND INNOVATION IN SCIENTIFIC RESEARCH}

N his Peter Le Neve Lecture to the Royal Society of
Arts on January 9, on "Progress and Innovation",
Mr. J. C. Duckworth, managing director of the National
Rosearch Development Corporation, said that in these days
of the large development and design team it is often
difficult to decide what is truly invention and what is
purely the logical outcome of applied research or develop-
ment work. The actual invention of a new device or
process can occur very soon after the requisite knowledge
is available, and indeed almost as part of the process of
acquiring it, or the invention may come long after the
necessary knowledge is available. On the other hand, the
inventor may be too far ahead of the 'frontiors of know-
ledge' for his ideas to be practicable.
Mr. Duckworth suggested that over the past two
conturies the nature of invention has changed. The
principle of designing new equipment to meet a need is
now well established and such design should not be con-
sidered invention unless it incorporates some novel
feature or concept beyond that which the ordinary design engineer can be expected to provide. The fact that ideas such as the hovercraft can be conceived by an individual should encourage those who believe that inventions may be possible by those outside the large resoarch anit development teams. Moreover, it is probable that individual inventors will have most success where a combination of different disciplines is required to produce the new idea.

After emphasizing that an invention only makes its impact if the economic and social climate is ready for its acceptance, in addition to the need for technical development to reach a sufficiently advancod stage, Mr. Duckworth observed that within the team the croative genius of invention is still required to make more than humdrum progress. The National Research Development Corpora. tion was set up partly due to the belief that inventions of obvious merit were being suppressed because their development jeopardized the position of established products; however, the Corporation found no reliables evidence of this. Development contracts involve an appreciable proportion of the effort and expenditure of 